\title{
Association of common promoter polymorphisms of MCP1 with hepatitis $B$ virus clearance
}

\author{
Byung Lae Park', Yoon Jun Kim², \\ Hyun Sub Cheong ${ }^{1}$, Lyoung Hyo $\mathrm{Kim}^{1}$, \\ Yoo Hyun Choi ${ }^{1}$, Hyo-Suk Lee ${ }^{2,3}$ and \\ Hyoung Doo Shin ${ }^{1}$
}

\author{
${ }^{1}$ Department of Genetic Epidemiology \\ SNP Genetics, Inc. \\ Seoul 153-803, Korea \\ ${ }^{2}$ Department of Internal Medicine and \\ Liver Research Institute \\ Seoul National University College of Medicine \\ Seoul 110-744, Korea \\ ${ }^{3}$ Corresponding author: Tel, 82-2-745-7557; \\ Fax, 82-2-744-8243; E-mail, hsleemd@snu.ac.kr
}

Accepted 16 November 2006

Abbreviations: $\mathrm{CH}$, chronic hepatitis; $\mathrm{HBV}$, hepatitis B virus; $\mathrm{HCC}$, hepatocellular carcinoma; LC, liver cirrhosis; SNP, single nucleotide polymorphism

\begin{abstract}
Hepatocellular carcinoma (HCC) is one of the most common malignant cancers closely associated with chronic infection by the hepatitis B virus (HBV) or the hepatitis $\mathrm{C}$ virus (HCV) throughout the world. In this study, the genetic associations of 20 known polymorphisms in eight candidate genes, including angiotensinogen (AGT), cadherin $1(C D H 1)$, cyclooxy genase 2 (COX2), monocyte chemotactic protein-1 (MCP1), multidrug resistance 1 (MDR1), chemokine ligand 5 (RANTES), thrombospondin 2 (THBS2), and thrombospondin 4 (THBS4), were analyzed in a large chronic hepatitis $B$ cohort $(n=1,095)$ recruited from the Korean population. In addition, three polymorphisms in chemokine receptor 4 (CXCR4) and vimentin (VIM) identified in this study were also genotyped. Using logistic regression analysis controlling possible confounding factors, one common (freq. $=0.367$ ) promoter polymorphism of MCP1 (MCP1-2518G $>A$ ) among analyzed polymorphisms was significantly associated with clearance of HBV infection. The frequency of homozygotes for the MCP1-2518A allele (MCP1-2518A/A) among chronic hepatitis $B$ virus (HBV) carrier patients was significantly higher than that among spontaneously
\end{abstract}

recovered (SR) subjects ( $17.7 \%$ vs. $10.4 \%)(\mathrm{OR}=1.78$, $P=0.004)$. Our findings imply a plausible explanation for the contribution of host genetic determinants to the variable outcome of HBV infection, which might provide valuable information for future genetic study in this area.

Keywords: angiotensinogen; cadherins; cyclooxygenase 2; carcinoma, hepatocellular; chemokine CCL2; hepatitis B virus; P-glycoprotein; polymorphism, single nucleotide; RANTES; thrombospondins

\section{Introduction}

Chronic infection with hepatitis $B$ virus (HBV) or hepatitis $\mathrm{C}$ virus (HCV) has a major role in the development of hepatocellular carcinoma (HCC) (Blumberg, 1984). Although the virologic features of the two viruses are entirely different, both viruses infect the human liver and initiate a series of processes leading to chronic hepatitis, cirrhosis, and HCC (Watson, 1999). Some epidemiological findings suggest different modes of disease progression and HCC promotion between HBV and HCV infection (Shiratori et al., 1995; Ikeda et al., 1998; Marotta et al., 2004). The mechanisms underlying such differences are unknown.

The clinical course of HBV infection varies from spontaneous recovery after acute hepatitis to a chronic persistent infection that may progress to cirrhosis or hepatocellular carcinoma. The mechanisms underlying resolution of acute HBV infection or its progression to chronicity remain undetermined. Age at infection has the most significant impact on the clinical outcome because chronic infection occurs in approximately $90 \%$ of infants infected at birth, in 25 to $50 \%$ of children infected between the ages of 1 and 5 years, and in less than $5 \%$ of those infected during adult life (Stevens et al., 1975; Coursaget et al., 1987; Tassopoulos et al., 1987). It is well known that the major mode of infection in HBV endemic areas, including Korea, is perinatal transmission (Stevens et al., 1975; Lok et al., 1987). The mechanisms underlying resolution of acute HBV infection or its progression to chronicity at each age group remain undetermined. When determining the chronicity of HBV infection within a group of patients who are presumed to have been infected at the same age, i.e. perinatally in Korea, it is apparent that the 
outcome of the infection does not appear to be determined by variations in virulence of the viral strains (Thursz et al., 1995; Cacciola et al., 2002), but that host factors are likely to influence disease outcome (Lin et al., 1989; Chisari and Ferrari 1995). Thus, it is conceivable that genetic differences play an additional role.

In recent years, a number of studies have shown that various genes could be involved in chronic liver diseases, liver regeneration, autoimmune hepatitis, primary biliary cirrhosis, and alcoholic liver disease, including monocyte chemotactic protein-1 (MCP1) (Marra et al., 1998), angiotensinogen (AGT) (Ishii et al., 2003; Medina et al., 2003; 2004; Moon et al., 2004), cadherin 1 (CDH1) (Tian et al., 1999; Wei et al., 2002), cyclooxygenase 2 (COX2) (Shiota et al., 1999), multidrug resistance 1 (MDR1) (Bao et al., 2000; Ros et al., 2003), chemokine ligand 5 (RANTES) (Apolinario Fernandez de Sousa and Garcia Monzon, 2003), thrombospondin 2 (THBS2), thrombospondin 4 (THBS4) (Ishii et al., 2003; Medina et al., 2003; 2004; Moon et al., 2004), chemokine receptor 4 (CXCR4) (Terada et al., 2003; Wald et al., 2004), and vimentin (VIM) (O'Brien et al., 1989).

MCP1 is structurally related to the CXC subfamily of cytokines (Copple et al., 2003). Secretion of MCP1 may contribute to the formation and maintenance of the inflammatory infiltrate observed during chronic liver disease (Marra et al., 1998). Alcoholic hepatitis and alcoholic cirrhosis are associated with distinct patterns of chemokine expression that are likely to be important factors in determining whether a patient develops acute parenchymal inflammation and alcoholic hepatitis, or chronic septal inflammation and alcoholic cirrhosis (Afford et al., 1998).

Angiotensinogen (AGT) is expressed in the liver and is cleaved by the enzyme renin in response to lowered blood pressure. AGT is involved in maintaining blood pressure and in the pathogenesis of essential hypertension and preeclampsia (Morgan et al., 1996). A statistically significant relationship was seen between inheritance of $A G T$-producing genotypes and the development of progressive hepatic fibrosis (Powell et al., 2000).

THBS2 and THBS4 belong to the thrombospondin family of disulfide-linked homotrimeric glycoproteins that mediate cell-to-cell and cell-to-matrix interactions. These proteins have been shown to function as potent inhibitors of tumor growth and angiogenesis (Kishi et al., 2003; Wessel et al., 2004). Previous studies have shown the expression and function of many pro- and antiangiogenic molecules in the setting of nontumoral chronic liver diseases and disease progression (Ishii et al., 2003; Medina et al., 2003; 2004; Moon et al., 2004).
Hepatic RANTES was found to be increased in patients with alcoholic hepatitis (Hirano et al., 2003). Wald et al. (2004) also showed an important role for the CXCR4 in recruitment and retention of immune cells in the liver during chronic $\mathrm{HCV}$ and $\mathrm{HBV}$ infection. Similarly, MDR1 and VIM were up-regulated in hepatocytes with severe liver disease (Ros et al., 2003) and in hepatoblastomas where mesenchymal tissue was present in the tumor (O'Brien et al., 1989).

$\mathrm{CDH} 1$ is a calcium-dependent cell-cell adhesion glycoprotein composed of five extracellular cadherin repeats, a transmembrane region and a highly conserved cytoplasmic tail. Mutations in this gene are correlated with gastric, breast, colorectal, thyroid, and ovarian cancers. Loss of function is thought to contribute to progression in cancer by increasing proliferation, invasion, and/or metastasis (Juhasz et al., 2003; Keller and Nigam 2003; Kowalski et al., 2003).

As a candidate gene association study, we investigated the genetic association of 23 polymorphisms in 10 candidate genes with different outcomes of HBV infection, including clearance of HBV and HCC occurrence.

\section{Materials and Methods}

\section{Study population and outcomes}

A total of 1,095 Korean subjects having either

Table 1. Clinical profiles of study subjects.

\begin{tabular}{|c|c|c|c|}
\hline \multirow{2}{*}{ Clinical profiles } & \multirow{2}{*}{ SR } & \multicolumn{2}{|c|}{$\mathrm{CC}$} \\
\hline & & $\mathrm{CH}$ or $\mathrm{LC}$ & $\mathrm{HCC}$ \\
\hline No. of subjects & 429 & 339 & 327 \\
\hline Age (mean (range)) & $54.9(28-79)$ & $49.9(22-85)$ & $58.3(25-79)$ \\
\hline Sex (male/female) & 240/189 & $274 / 65$ & $277 / 50$ \\
\hline $\begin{array}{l}\mathrm{HBeAg} \\
\text { (positive rate, \%) }\end{array}$ & 0 & 33.5 & 19.6 \\
\hline $\begin{array}{l}\text { HBeAb } \\
\text { (positive rate, \%) }\end{array}$ & 38.2 & 47.3 & 63.8 \\
\hline $\begin{array}{l}\text { HBsAg } \\
\text { (positive rate, \%) }\end{array}$ & 0 & 100.0 & 100.0 \\
\hline $\begin{array}{l}\text { HBsAb } \\
\text { (positive rate, \%) }\end{array}$ & 100.0 & 0 & 0 \\
\hline $\begin{array}{l}\text { Urine albumin } \\
\text { (positive rate, \%) }\end{array}$ & 0 & 8.5 & 15.0 \\
\hline $\begin{array}{l}\text { Urine blood } \\
\text { (positive rate, \%) }\end{array}$ & 28.7 & 14.7 & 24.8 \\
\hline
\end{tabular}

$\mathrm{SR}$, spontaneous recovery; CC, chromic carrier; $\mathrm{CH}$, chronic hepatitis; LC, liver cirrhosis; HCC, hepatocellular carcinoma 
present or past evidence of HBV infection were prospectively enrolled from the outpatient clinic of the liver unit or from the Center for Health Promotion of Seoul National University Hospital between January 2001 and August 2003. Subjects were placed in two different groups according to serologic markers: the chronic carrier (CC) group, or the spontaneous recovery (SR) group. The CC and SR cohorts consisted of 666 and 429 subjects, respectively (Table 1). The diagnoses of the CC and SR subjects were established by repeated seropositivity for the hepatitis B surface antigen (HBsAg) (Enzygnost $^{\circledR}$ HBsAg 5.0; Dade Behring, Marburg, Germany) over a 6-month period, and for both anti-HBs (Enzygnost ${ }^{\circledR}$ Anti-HBs II; Dade Behring, Marburg, Germany) and anti-HBc (AB-Corek; DiaSorin s.r.l., Saluggia, Italy) of the IgG type without $\mathrm{HBsAg}$, respectively. Asymptomatic HBV carriers were also included in CC group. These patients usually have inactive liver disease on liver biopsy. However, it has been known that in these patients, HBV continues to replicate, albeit very low levels, some patients have residual liver disease, and HCC develop frequently. The CC group was further divided into 2 subgroups, i.e., those without (the $\mathrm{CH} / \mathrm{LC}$ group; $n=339$ ) and those with $\mathrm{HCC}$ (the HCC group; $n=327$ ), according to the absence or presence of HCC, respectively. HCC was diagnosed as described previously (Bruix et al., 2001). We excluded subjects who were positive for anti-HBs but not for anti-HBc, and those positive for anti-HCV or anti-HIV (GENEDIA ${ }^{\circledR}$; Greencross Life Science Corp., Yongin-shi, Korea, $\mathrm{HCV}^{\circledR} 3.2$; Dong-A Pharmaceutical Co., Seoul, Korea). The patients who had any other types of liver disease such as autoimmune hepatitis, toxic hepatitis, primary biliary cirrhosis, or Budd-Chiari syndrome were also excluded. No patients had a previous history of immunosuppression or anti-viral treatment. Informed consent was obtained from each patient, and the Institutional Review Board of Human Research at Seoul National University Hospital approved the study protocol. The clinical parameters are summarized in Table 1.

\section{Sequence analysis of the human CXCR4 and VIM}

We have sequenced exons and their flanking regions, including the promoter region $(1.5 \mathrm{~kb})$, to discover variants in 24 Korean unregulated individual DNA samples using the ABI PRISM 3700 DNA analyzer (Applied Biosystems, Foster City, CA). Primer sets for the amplification and sequencing analysis of CXCR4 and VIM were designed based on GenBank sequences (Ref. Genome seq.; NT_ 005058 released on 19. Aug. 2004 and NT_077569 released on 20. Aug. 2004, respectively). Informa- tion regarding primers is available on our website (http://www.snp-genetics.com/reference/Supplement ary information to HBV.doc). Sequence variants were verified by chromatograms.

\section{Genotyping with fluorescence polarization detection}

Twenty polymorphisms of eight candidate genes that might be implicated in clearance of HBV infection and $\mathrm{HCC}$ occurrence were genotyped in this study, including $-532 C>T,-217 G>A,-6 A>G$, and $+3889 C$ $>T$ in $A G T-472$ insdelA, $-285 C>A,+76003 A>C$, $+84762 C>G$, and $+86123 C>T$ in $C D H 1$ (Humar et al., 2002; Nakamura et al., 2002; Wang et al., 2003); $-162 C>G,+3552 G>A$, and $+5789 T>C$ in COX2 (Fritsche et al., 2001); $-2518 G>A$ and $-2076 A>T$ in MCP1 (Aguilar et al., 2001; Szalai et al., 2001; Kim et al., 2002); +69219G $>T$ and $+91191 T>C$ in MDR1 (Jamroziak et al., 2004; Kajinami et al., 2004 ); $-403 G>A$ and $-28 C>G$ in RANTES (Liu et al., 1999); $+36412 T>G$ in THBS2; and $+30275 G>$ $C$ in THBS4 (Topol et al., 2001; Boekholdt et al., 2002). In addition, three polymorphisms in chemokine receptor $4(C X C R 4)$ and vimentin (VIM), identified in this study, were also genotyped (Table 2).

For genotyping of 23 polymorphic sites, amplifying primers and probes were designed for TaqMan ${ }^{\circledR}$ (An et al., 2002). Primer Express (Applied Biosystems) was used to design both the PCR primers and the MGB TaqMan probes. One allelic probe was labeled with the FAM dye and the other with the fluorescent VIC dye. Typically, PCR was run in the TaqMan Universal Master mix without UNG (Applied Biosystems) at primer concentration of $900 \mathrm{nM}$ and TaqMan MGB-probe concentration of $200 \mathrm{nM}$. The reaction was performed in a 384-well format in a total reaction volume of $5 \mu \mathrm{l}$ using $20 \mathrm{ng}$ of genomic DNA. The plate was then placed in a thermal cycler (PE 9700, Applied Biosystems) and heated for 2 min at $50^{\circ} \mathrm{C}$ and for $10 \mathrm{~min}$ at $95^{\circ} \mathrm{C}$, followed by 40 cycles of $95^{\circ} \mathrm{C}$ for $15 \mathrm{~s}$ and $60^{\circ} \mathrm{C}$ for $1 \mathrm{~min}$. The TaqMan assay plate was then transferred to a Prism $7900 \mathrm{HT}$ instrument (Applied Biosystems) where the fluorescence intensity of each well was read. Fluorescence data files from each plate were analyzed by automated software (SDS 2.1). Detailed information concerning the primers can be obtained at the website mentioned above.

\section{Statistics}

We examined Lewontin's D' (|D'|) and LD coefficient $r^{2}$ between all pairs of biallelic loci (Hedrick, 1987). Haplotypes of each individual were inferred using the algorithm developed by Stephens et al. (2001), 
Table 2. Analysis for HBV clearance and HCC occurrence on CH or LC with SNPs and haplotypes in candidate genes in Korean subjects.

\begin{tabular}{|c|c|c|c|c|c|c|c|c|}
\hline \multirow{3}{*}{ Gene } & \multirow{3}{*}{ Allele } & \multirow{3}{*}{ Allele } & \multicolumn{3}{|c|}{ HBV clearance } & \multicolumn{3}{|c|}{ HCC occurrence } \\
\hline & & & \multicolumn{2}{|c|}{ Allele distribution [n (\%)] } & \multirow{2}{*}{$\begin{array}{c}\text { Permutation } \\
P \text {-value }\end{array}$} & \multicolumn{2}{|c|}{ Allele distribution [n (\%)] } & \multirow{2}{*}{$\begin{array}{c}\text { Permutation } \\
P \text {-value }\end{array}$} \\
\hline & & & $\mathrm{CC}$ & SR & & $\mathrm{HCC}$ & No HCC & \\
\hline \multirow[t]{2}{*}{$C X C R 4^{* *}$} & $+2547 C>T$ & C & 1,166 (89.6) & 767 ( 89.4) & 0.94 & $566(89.8)$ & $587(89.2)$ & 0.71 \\
\hline & & $\mathrm{T}$ & $136(10.5)$ & $91(10.6)$ & & $64(10.2)$ & $71(10.8)$ & \\
\hline \multirow[t]{4}{*}{$V I M^{\star \star}$} & $-510 A>G$ & $A$ & $839(71.8)$ & $603(72.0)$ & 0.96 & $425(73.0)$ & $403(70.5)$ & 0.36 \\
\hline & & G & $329(28.2)$ & 235 ( 28.0) & & $157(27.0)$ & 169 ( 29.6) & \\
\hline & $+6750 G>C$ & G & $862(70.9)$ & $605(70.8)$ & 1.00 & $432(72.2)$ & $419(69.4)$ & 0.28 \\
\hline & & C & $354(29.1)$ & 249 ( 29.2) & & $166(27.8)$ & 185 ( 30.6) & \\
\hline \multirow{10}{*}{$A G T^{*}$} & $-532 C>T$ & C & $999(83.3)$ & 694 ( 82.2) & 0.56 & $498(83.0)$ & 488 ( 83.3) & 0.94 \\
\hline & & $\mathrm{T}$ & 201 (16.8) & $150(17.8)$ & & $102(17.0)$ & $98(16.7)$ & \\
\hline & $-217 G>A$ & G & $950(83.6)$ & $701(83.1)$ & 0.76 & $485(83.6)$ & $452(83.4)$ & 0.93 \\
\hline & & $A$ & $186(16.4)$ & $143(16.9)$ & & $95(16.4)$ & $90(16.6)$ & \\
\hline & $-6 A>G$ & $A$ & $1,010(80.2)$ & $687(80.1)$ & 0.95 & $467(80.0)$ & $531(80.2)$ & 0.94 \\
\hline & & G & 250 (19.8) & $171(19.9)$ & & $117(20.0)$ & $131(19.8)$ & \\
\hline & $+3889 \mathrm{C}>T$ & $\mathrm{C}$ & $1,135(89.1)$ & $765(89.0)$ & 0.94 & $550(90.2)$ & $571(87.9)$ & 0.20 \\
\hline & & $\mathrm{T}$ & 139 (10.9) & $95(11.1)$ & & $60(9.8)$ & $79(12.2)$ & \\
\hline & $h t 3$ & $-/-$ & 999 (83.7) & 706 ( 82.5) & 0.75 & 498 (83.6) & 488 ( 83.6) & 0.35 \\
\hline & & ht3/ht3 & $195(16.3)$ & $150(17.5)$ & & $98(16.4)$ & $96(16.4)$ & \\
\hline \multirow{12}{*}{$C D H 1^{* *}$} & $-472 i n s d e l A$ & DEL & 912 (74.4) & $647(75.2)$ & 0.68 & 447 (76.5) & 454 ( 72.3) & 0.10 \\
\hline & & INS & $314(25.6)$ & $213(24.8)$ & & $137(23.5)$ & $174(27.7)$ & \\
\hline & $-285 C>A$ & $C$ & $1,058(82.5)$ & $694(80.7)$ & 0.30 & $498(81.6)$ & $549(83.4)$ & 0.41 \\
\hline & & A & 224 (17.5) & 166 ( 19.3) & & $112(18.4)$ & 109 ( 16.6) & \\
\hline & $+76003 A>C$ & $A$ & 1,268 (99.8) & $857(99.9)$ & 1.00 & 605 (99.8) & 649 ( 99.9) & 1.00 \\
\hline & & C & $2(0.2)$ & $1(\quad 0.1)$ & & $1(0.2)$ & $1(\quad 0.2)$ & \\
\hline & $+84762 C>G$ & $\mathrm{C}$ & $1,307(99.2)$ & $849(99.0)$ & 0.65 & $632(98.8)$ & $661(99.6)$ & 0.14 \\
\hline & & G & $11(0.8)$ & $9(1.1)$ & & $8(1.3)$ & $3(0.5)$ & \\
\hline & $+86123 C>T$ & C & $783(61.2)$ & 505 ( 58.7) & 0.27 & $371(60.4)$ & $402(61.7)$ & 0.69 \\
\hline & & $\mathrm{T}$ & 497 (38.8) & $355(41.3)$ & & $243(39.6)$ & $250(38.3)$ & \\
\hline & $h t 3$ & $-/-$ & 980 (78.0) & $690(80.2)$ & 0.24 & $470(77.8)$ & $500(78.4)$ & 0.84 \\
\hline & & $\mathrm{ht3} / \mathrm{ht} 3$ & 276 (22.0) & $170(19.8)$ & & $134(22.2)$ & 138 ( 21.6) & \\
\hline \multirow[t]{6}{*}{$\operatorname{COX} 2^{*}$} & $-162 C>G$ & C & 1,251 (99.3) & 846 ( 98.8) & 0.35 & 608 (99.0) & 629 ( 99.5) & 0.33 \\
\hline & & G & $9(0.7)$ & $10(1.2)$ & & $6(1.0)$ & $3(0.5)$ & \\
\hline & $+3552 G>A$ & G & 1,297 (99.3) & 847 ( 99.0) & 0.47 & $612(99.0)$ & 671 ( 99.6) & 0.32 \\
\hline & & $\mathrm{A}$ & $9(0.7)$ & $9(1.1)$ & & $6(1.0)$ & $3(0.5)$ & \\
\hline & $+5789 T>C$ & $\mathrm{~T}$ & $1,283(99.9)$ & 858 (100.0) & 1.00 & 613 (99.8) & $656(100.0)$ & 0.48 \\
\hline & & C & $1(0.1)$ & $0(0.0)$ & & $1(0.2)$ & $0(0.0)$ & \\
\hline \multirow[t]{6}{*}{$M C P 1^{*}$} & $-2518 G>A$ & G & 742 (61.2) & $566(66.6)$ & 0.01 & 367 (61.4) & 366 ( 61.0) & 0.91 \\
\hline & & A & 470 (38.8) & 284 ( 33.4) & & $231(38.6)$ & 234 ( 39.0$)$ & \\
\hline & $-2076 A>T$ & A & $1,214(93.5)$ & $812(94.6)$ & 0.31 & 579 (93.7) & $622(93.4)$ & 0.91 \\
\hline & & $\mathrm{T}$ & $84(6.5)$ & $46(5.4)$ & & $39(6.3)$ & $44(6.6)$ & \\
\hline & $h t 2$ & $-/-$ & 818 (67.9) & 611 ( 71.9) & 0.06 & 403 (68.3) & 405 ( 67.5) & 0.81 \\
\hline & & ht2/ht2 & 386 (32.1) & $239(28.1)$ & & 187 (31.7) & 195 ( 32.5) & \\
\hline$M D R 1^{* *}$ & $+69219 \mathrm{G}>T$ & G & $586(54.2)$ & $448(53.9)$ & 0.92 & $268(53.0)$ & $311(55.3)$ & 0.45 \\
\hline & & $\mathrm{T}$ & $496(45.8)$ & $384(46.2)$ & & $238(47.0)$ & $251(44.7)$ & \\
\hline & $+91191 T>C$ & $\mathrm{~T}$ & 840 (63.8) & $547($ ( 63.9) & 1.00 & $392(61.8)$ & $440(65.9)$ & 0.13 \\
\hline & & C & 476 (36.2) & $309(36.1)$ & & $242(38.2)$ & $228(34.1)$ & \\
\hline & $h t 3$ & $-/-$ & 963 (89.0) & 733 ( 88.3) & 0.66 & 454 (89.7) & 497 ( 88.4) & 0.55 \\
\hline & & ht3/ht3 & 119 (11.0) & $97(11.7)$ & & $52(10.3)$ & $65(11.6)$ & \\
\hline RANTES* & $-403 G>A$ & G & 755 (58.5) & $508(59.5)$ & 0.69 & 361 (58.6) & $387(58.6)$ & 1.00 \\
\hline & & A & 535 (41.5) & 346 ( 40.5) & & 255 (41.4) & $273(41.4)$ & \\
\hline & $-28 C>G$ & C & $668(79.9)$ & 666 ( 83.3) & 0.09 & 307 (79.1) & $353(80.6)$ & 0.60 \\
\hline & & G & 168 (20.1) & $134(16.8)$ & & $81(20.9)$ & $85($ (19.4) & \\
\hline & $h t 2$ & $-/-$ & 651 (78.1) & $609(76.5)$ & 0.47 & 296 (76.7) & $348(79.5)$ & 0.34 \\
\hline & & ht2/ht2 & 183 (21.9) & $187(23.5)$ & & $90(23.3)$ & $90(20.6)$ & \\
\hline THBS2 ${ }^{\star *}$ & $+36412 T>G$ & $\mathrm{~T}$ & $1,155(89.5)$ & 769 ( 90.1) & 0.71 & $548(90.4)$ & 594 ( 88.7) & 0.31 \\
\hline & & G & $135(10.5)$ & $85(10.0)$ & & 58 ( 9.6) & $76(11.3)$ & \\
\hline THBS4** & $+30275 G>C$ & G & $1,232(93.8)$ & 819 ( 95.5) & 0.10 & 589 (93.8) & $630(93.8)$ & 1.00 \\
\hline & & $\mathrm{C}$ & $82(6.2)$ & $39(4.6)$ & & 39 ( 6.2) & $42(6.3)$ & \\
\hline
\end{tabular}

${ }^{*}$ Transcriptional start site is denoted by +1 . ${ }^{*}$ Translational start site is denoted by +1 . Permutation $P$-values were calculated by SAS. All patients included in study were HBsAg-positive (chronic hepatitis). 
Table 3. Logistic analysis of clearance of HBV with MCP1 gene polymorphisms in Korean subjects.

\begin{tabular}{|c|c|c|c|c|c|c|c|c|c|c|c|}
\hline \multirow[b]{2}{*}{ Locus } & \multirow[b]{2}{*}{ Genotype } & \multicolumn{2}{|c|}{ Genotype distribution [n(\%)] } & \multicolumn{2}{|c|}{ Referent } & \multicolumn{2}{|c|}{ Co-dominant } & \multicolumn{2}{|c|}{ Dominant } & \multicolumn{2}{|c|}{ Recessive } \\
\hline & & $\mathrm{CC}$ & SR & $\begin{array}{c}\text { OR } \\
(95 \% \mathrm{Cl})\end{array}$ & $P$ & $\begin{array}{c}\text { OR } \\
(95 \% \mathrm{Cl})\end{array}$ & $P$ & $\begin{array}{c}\text { OR } \\
(95 \% \mathrm{Cl})\end{array}$ & $P$ & $\begin{array}{c}\text { OR } \\
(95 \% \mathrm{Cl})\end{array}$ & $P$ \\
\hline \multirow[t]{3}{*}{$-2518 G>A$} & GG & $243(40.1)$ & $185(43.5)$ & 1 & & & & & & & \\
\hline & $A G$ & $256(42.2)$ & $196(46.1)$ & $\begin{array}{c}0.94 \\
(0.71-1.25)\end{array}$ & 0.67 & $\begin{array}{c}1.20 \\
(0.99-1.44)\end{array}$ & 0.06 & $\begin{array}{c}1.08 \\
(0.83-1.41)\end{array}$ & 0.56 & $\begin{array}{c}1.78 \\
(1.20-2.63)\end{array}$ & 0.004 \\
\hline & $A A$ & $107(17.7)$ & $44(10.4)$ & $\begin{array}{c}1.32 \\
(1.07-1.62)\end{array}$ & 0.009 & & & & & & \\
\hline \multirow[t]{3}{*}{$-2076 A>T$} & $A A$ & $568(87.5)$ & $385(89.7)$ & 1 & & & & & & & \\
\hline & $A T$ & $78(12.0)$ & $42(9.8)$ & $\begin{array}{c}1.40 \\
(0.92-2.14)\end{array}$ & 0.11 & $\begin{array}{c}1.38 \\
(0.94-2.03)\end{array}$ & 0.10 & $\begin{array}{c}1.41 \\
(0.94-2.13)\end{array}$ & 0.10 & $\begin{array}{c}1.50 \\
(0.23-9.79)\end{array}$ & 0.67 \\
\hline & $T T$ & $3(0.5)$ & $2(0.5)$ & $\begin{array}{c}1.25 \\
(0.49-3.18)\end{array}$ & 0.65 & & & & & & \\
\hline \multirow[t]{3}{*}{$h t 2$} & $-/-$ & $293(48.7)$ & $213(50.1)$ & 1 & & & & & & & \\
\hline & $-/ h t 2$ & $232(38.5)$ & $185(43.5)$ & $\begin{array}{c}0.83 \\
(0.63-1.10)\end{array}$ & 0.19 & $\begin{array}{c}1.11 \\
(0.91-1.35)\end{array}$ & 0.33 & $\begin{array}{c}0.96 \\
(0.74-1.24)\end{array}$ & 0.74 & $\begin{array}{c}1.92 \\
(1.19-3.08)\end{array}$ & 0.007 \\
\hline & $h t 2 / h t 2$ & $77(12.8)$ & $27(6.4)$ & $\begin{array}{c}1.34 \\
(1.05-1.71)\end{array}$ & 0.02 & & & & & & \\
\hline
\end{tabular}

Logistic regression models were used for calculating odds ratios (95\% confidence interval) and corresponding $P$-values for each SNP site and haplotype using SAS. $P$-values of co-dominant, dominant, and recessive models are also given. Age (continuous value) and $\operatorname{sex}(\operatorname{male}=0$, female $=1$ ) were adjusted by inclusion in logistic analysis as covariates.

which (PHASE) uses a Bayesian approach incorporating a priori expectations of haplotypic structure from population genetic and coalescent theory. Genetic effects of inferred haplotypes were analyzed in the same way as SNPs. The permutation test was also performed to test deviation of allelic frequencies of SNPs and haplotypes by using SAS (proc multtest). Distribution was estimated by evaluating the statistics for a random sampling of 10,000 iterated permutations at fixing the total numbers of both the cases and controls. $P$-value is estimated by the proportion of permutations for which the permutated data test statistic ( $\left.P_{\text {permuted }}\right)$ is greater than the initially observed test statistic $\left(P_{\text {observed }}\right)$, so permutation $P=P\left(P_{\text {observed }}>P_{\text {permuted }}\right)$ (Table 2$)$.

Logistic regression models were used for calculating odds ratios (95\% confidential interval) and corresponding $P$-values controlling for age (continuous value) and sex (male $=0$, female $=1$ ) as covariates. In our analysis of HCC occurrence, LC $(\mathrm{LC}=1$, no $L C=0$ ) and $\mathrm{HBeAg}$ (negative $=0$, blank $=1$, positive $=2$ ) were also used as covariates (Table 3).

\section{Results}

The first critical step in conducting candidate gene studies is the choice of suitable candidate genes that may plausibly play a relevant role in the process or disease under investigation. The candidate gene approach for discovering genetic markers uses experimentally derived a priori knowledge about diseases, and we selected ten candidate genes and their polymorphisms, previously reported the relationship to the various liver diseases, for association study with HBV infection and HCC occurrence.

To discover polymorphisms in CXCR4 and VIM, we performed direct DNA sequencing in 24 unrelated Korean individuals within exons and their boundaries, including the $1.5 \mathrm{~kb}$ upstream region of two genes. We identified one sequence variant $(+2547 C>T)$ in exon2 of CXCR4 and five variants (two in promoter $[-510 A>G$ and $-312 G>C$ ], one in 5' UTR $[-22 G>C]$, and two in introns [+6750G $>C$ and $+7379 C>T]$ ) in VIM, respectively (http://www. snp-genetics.com/reference/Supplementary information to HBV.doc). CXCR4+2547C $>T$, VIM $-510 A>G$, and $V I M+6750 G>C$ were selected for larger-scale genotyping $(n=1,095)$, considering their allele frequencies, haplotype-tagging status, and LDs among polymorphisms. Allele frequencies of all of screened polymorphisms were estimated (http://www.snp-genetics. com/reference/Supplementary information to HBV. doc).

Through pair-wise linkage analysis in a Korean chronic hepatitis $B$ cohort, we have found that three sets of polymorphisms in COX2 and two of MCP1 
were in complete LD $\left(\left|D^{\prime}\right|=1\right.$ and $\left.r^{2} \neq 1\right)$, and that four sets of polymorphisms in $A G T$ were in almost complete LD. Another set of polymorphisms in CDH1, RANTES, MDR1, and VIM showed strong LDs within genes (http://www.snp-genetics.com/ reference/Supplementary information to HBV.doc). Among the haplotypes, only $h t 2$ in $M C P 1$, ht1 in $A G T$, ht1 in CDH1, ht3 in MDR1, and ht2 in RANTES were used for further analysis because other haplotypes were almost (or completely) tagged by a single SNP or the frequencies were too low.

Genotype distributions were analyzed among SR, $\mathrm{CC}$, and $\mathrm{HCC}$ subjects using logistic regression models. One common promoter polymorphism in MCP1 (MCP1-2518G $>A$ ) was found to be significantly associated with clearance of HBV infection, whereas no significant associations were observed between other candidate gene polymorphisms and the clearance of $\mathrm{HBV}$ infection (Table 2). The frequency of MCP1-2518A allele (MCP1-2518A/A) among the chronic hepatitis $B$ virus (HBV) carrier patients was significantly higher than for the spontaneously recovered (SR) subjects $(38.8 \%$ vs. $33.4 \%$ ) (permutation $P=0.01$ ). Similarly, the effect of the homozygote for the " $A$ " allele of $-2518 \mathrm{G} / A$ also was apparent in the referent model (OR $=1.32, P=$ 0.009 , Table 3 ). Consistent associations revealed in referent- and recessive-analyzing models clearly demonstrated the recessive mode of effect of the " $A$ " allele of $-2518 \mathrm{G} / A$. In further haplotype association analysis, $h t 2[A-A]$ showed similar association with clearance of $\mathrm{HBV}$. However, considering that $h t 2$ is mostly ( $>93 \%$ ) tagged by $2518 G>A$, this genetic effect might be coming from $-2518 G>A$. In the analysis of $\mathrm{HCC}$ occurrence in Korean population, all candidate gene polymorphisms were not associated (Table 2).

\section{Discussion}

MCP1, a member of the small inducible gene (SIG) family, plays a role in the recruitment of monocytes to sites of injury and infection. It has been reported that $M C P$ polymorphisms in the regulatory region affect the level of MCP1 expression in response to an inflammatory stimulus. Interestingly, the associated polymorphism (MCP1-2518G $>A$ ), which showed significant association with clearance of $\mathrm{HBV}$, has been reported to alter MCP1 expression, whereas no effect by the other promoter variant $(M C P 1-2076 A>T)$ has been reported (Rovin et al., 1999). IL1B-treated peripheral blood mononuclear cells from individuals heterozygous or homozygous for the $G$ allele at $M C P 1-2518 G>A$ produce more MCP1 than cells from individuals homozygous for the A allele (Rovin et al., 1999; Cho et al., 2004). Altered level of MCP1 expression due to genotype allele could contribute to the formation and maintenance of the inflammatory infiltrate during chronic liver disease and severe hepatic inflammation and fibrosis (Marra et al., 1998; Muhlbauer et al., 2003). Involvement of MCP1 polymorphisms in the regulatory region has been reported in various diseases including asthma (Szalai et al., 2001), systemic lupus erythematosus (Aguilar et al., 2001; Kim et al., 2002), HCV progression (Muhlbauer et al., 2003; Tagami et al., 2003), and HBV infection in this study. Different MCP-1 expressions by alternative alleles of $-2518 G>A$ (Rovin et al., 1999; Muhlbauer et al., 2003) consistently suggest functional and/or causal effects of this important variant.

The functional effects of MCP1-2518G $>A$ on the progression and severity of various diseases were mainly accompanied by the elevated levels of MCP1 due to $G$ allele of $M C P 1-2518 G>A$, whereas $A$ allele of $M C P 1-2518 G>A$, causing lower level of MCP1, contributed to the chronicity of HBV in this study. Although the mechanisms underlying clearance of HBV infection by lower MCP1 expression of the "A" allele of MCP1-2518G $>A$ are not completely understood, several clues might suggest possible explanations. For instance, MCP-1 might contribute to the formation and maintenance of the inflammatory infiltrate observed during chronic liver disease (Marra et al., 1998). In an animal study, MCP1-deficient mice were unable to mount type 2 helper cell (TH2) responses ( $\mathrm{Gu}$ et al., 2000). Consequently, these mice did not accomplish the immunoglobulin subclass switch that is characteristic of $\mathrm{TH} 2$ responses and were resistant to Leishmania major. MCP1 influences both innate immunity, through effects on monocytes, and adaptive immunity, through control of $\mathrm{T}$ helper cell polarization ( $\mathrm{Gu}$ et al., 2000).

The effects of MCP1 polymorphisms on the resolution of HBV infection were not dramatic in the present study. However, when considering 1) that there were evidences for functional differences mediated by MCP1-2518G $>A$ (Rovin et al., 1999; Cho et al., 2004), consequently, affecting disease susceptibility of various diseases in previous studies (Aguilar et al.; 2001; Szalai et al., 2001; Kim et al., 2002), (Rovin et al., 1999; Muhlbauer et al., 2003; Tagami et al., 2003), and 2) that altered level of MCP1 expression have been reported to be involved in the inflammatory infiltrate during chronic liver disease and severe hepatic inflammation and fibrosis (Marra et al., 1998; Muhlbauer et al., 2003), the significance of associations with the clearance of HBV infection might be noteworthy. Further biological and/or functional evidence would be needed to 
confirm the suggestive associations of MCP1 polymorphisms with HBV infection.

In summary, we examined the genetic association of 23 polymorphisms in ten candidate genes. Among 23 polymorphisms, one common promoter variant in MCP1 $(-2518 G>A)$, which is associated with lower MCP1 expression, was significantly associated with the resolution of HBV infection in a Korean HBV study. Haplotype analysis revealed that MCP1-ht2 $[A-A]$ was also significantly associated with HBV clearance, which possibly tracks the genetic effect of the promoter variant. Our findings imply that variations in the genes governing the level of constitutive and inducible MCP1 are an important factor that might explain the variable outcome of $\mathrm{HBV}$ infection and offer an approach to elucidating the molecular mechanisms of HBV clearance. This finding might also provide a new perspective on antiviral approaches for the treatment of patients with chronic hepatitis $B$.

\section{Acknowledgement}

We greatly acknowledge the study participants and their families, who participated in the HBV cohort study at Seoul National University. This work was supported by grant number FG04-12-02 of 21C Frontier Functional Human Genome Project from the Ministry of Science and Technology of Korea.

\section{References}

Afford SC, Fisher NC, Neil DA, Fear J, Brun P, Hubscher SG, Adams $\mathrm{DH}$. Distinct patterns of chemokine expression are associated with leukocyte recruitment in alcoholic hepatitis and alcoholic cirrhosis. J Pathol 1998;186:82-9

Aguilar F, Gonzalez-Escribano MF, Sanchez-Roman J, Nunez-Roldan A. MCP-1 promoter polymorphism in Spanish patients with systemic lupus erythematosus. Tissue Antigens 2001;58:335-8

An P, Nelson GW, Wang L, Donfield S, Goedert JJ, Phair J, Vlahov D, Buchbinder S, Farrar WL, Modi W, O'Brien SJ, Winkler CA. Modulating influence on HIVIAIDS by interacting RANTES gene variants. Proc Natl Acad Sci USA 2002; 99:10002-7

Apolinario Fernandez de Sousa A, Garcia Monzon C Role of chemokines in the pathogenesis of liver diseases. Rev Esp Enferm Dig 2003;95:614-620:607-13

Bao JJ, Lee BP, Stephens LC, Sahin AA, Van NT, Johnston DA, Ou CN, Kuo MT. Elevated expression of hepatic proliferative markers during early hepatocarcinogenesis in hepatitis-B virus transgenic mice lacking mdr1a-encoded P-glycoprotein. Mol Carcinog 2000;29:103-11

Blumberg BS. Hepatitis B virus and the control of hepatocellular carcinoma. IARC Sci Publ 1984:243-61
Boekholdt SM, Trip MD, Peters RJ, Engelen M, Boer JM, Feskens EJ, Zwinderman AH, Kastelein JJ, Reitsma PH. Thrombospondin-2 polymorphism is associated with a reduced risk of premature myocardial infarction. Arterioscler Thromb Vasc Biol 2002;22:e24-7

Bruix J, Sherman M, Llovet JM, Beaugrand M, Lencioni R, Burroughs AK, Christensen E, Pagliaro L, Colombo M, Rodes J. Clinical management of hepatocellular carcinoma. Conclusions of the Barcelona-2000 EASL conference. European Association for the Study of the Liver. J Hepatol 2001; 35:421-30

Cacciola I, Cerenzia G, Pollicino T, Squadrito G, Castellaneta S, Zanetti AR, Mieli-Vergani G, Raimondo G. Genomic heterogeneity of hepatitis $B$ virus (HBV) and outcome of perinatal HBV infection. J Hepatol 2002;36:426-32

Chisari FV, Ferrari C. Hepatitis B virus immunopathogenesis. Annu Rev Immunol 1995;13:29-60

Cho ML, Kim JY, Ko HJ, Kim YH, Kim WU, Cho CS, Kim HY, Hwang SY. The MCP-1 promoter -2518 polymorphism in Behcet's disease: correlation between allele types, MCP-1 production and clinical symptoms among Korean patients. Autoimmunity 2004;37:77-80

Copple BL, Ganey PE, Roth RA. Liver inflammation during monocrotaline hepatotoxicity. Toxicology 2003;190:155-69

Coursaget P, Yvonnet B, Chotard J, Vincelot P, Sarr M, Diouf C, Chiron JP, Diop-Mar I. Age- and sex-related study of hepatitis $B$ virus chronic carrier state in infants from an endemic area (Senegal). J Med Virol 1987;22:1-5

Fritsche E, Baek SJ, King LM, Zeldin DC, Eling TE, Bell DA. Functional characterization of cyclooxygenase-2 polymorphisms. J Pharmacol Exp Ther 2001;299:468-76

Gu L, Tseng S, Horner RM, Tam C, Loda M, Rollins BJ. Control of $\mathrm{TH} 2$ polarization by the chemokine monocyte chemoattractant protein-1. Nature 2000;404:407-11

Hedrick PW. Gametic disequilibrium measures: proceed with caution. Genetics 1987;117:331-41

Hirano F, Kobayashi A, Makino I. Inhibition of TNF-alphainduced RANTES expression in human hepatocyte-derived cells by fibrates, the hypolipidemic drugs. Int Immunopharmacol 2003;3:225-32

Humar B, Graziano F, Cascinu S, Catalano V, Ruzzo AM, Magnani M, Toro T, Burchill T, Futschik ME, Merriman T, Guilford P. Association of CDH1 haplotypes with susceptibility to sporadic diffuse gastric cancer. Oncogene 2002;21:8192-5

Ikeda K, Saitoh S, Suzuki Y, Kobayashi M, Tsubota A, Fukuda M, Koida I, Arase Y, Chayama K, Murashima N, Kumada H. Interferon decreases hepatocellular carcinogenesis in patients with cirrhosis caused by the hepatitis B virus: a pilot study. Cancer 1998;82:827-35

Ishii Y, Nakasato Y, Kobayashi S, Yamazaki Y, Aoki T. A study on angiogenesis-related matrix metalloproteinase networks in primary hepatocellular carcinoma. J Exp Clin Cancer Res 2003;22:461-70

Jamroziak K, Mlynarski W, Balcerczak E, Mistygacz M, Trelinska J, Mirowski M, Bodalski J, Robak T. Functional 
C3435T polymorphism of MDR1 gene: an impact on genetic susceptibility and clinical outcome of childhood acute lymphoblastic leukemia. Eur J Haematol 2004; 72:314-21

Juhasz M, Ebert MP, Schulz HU, Rocken C, Molnar B, Tulassay Z, Malfertheiner P. Dual role of serum soluble E-cadherin as a biological marker of metastatic development in gastric cancer. Scand J Gastroenterol 2003;38:850-5

Kajinami K, Brousseau ME, Ordovas JM, Schaefer EJ. Polymorphisms in the multidrug resistance-1 (MDR1) gene influence the response to atorvastatin treatment in a gender-specific manner. Am J Cardiol 2004;93:1046-50

Keller SH, Nigam SK. Biochemical processing of E-cadherin under cellular stress. Biochem Biophys Res Commun 2003; $307: 215-23$

Kim HL, Lee DS, Yang SH, Lim CS, Chung JH, Kim S, Lee JS, Kim YS. The polymorphism of monocyte chemoattractant protein-1 is associated with the renal disease of SLE. Am J Kidney Dis 2002;40:1146-52

Kishi M, Nakamura M, Nishimine M, Ishida E, Shimada K, Kirita $\mathrm{T}$, Konishi N. Loss of heterozygosity on chromosome $6 \mathrm{q}$ correlates with decreased thrombospondin-2 expression in human salivary gland carcinomas. Cancer Sci 2003;94:530535

Kowalski PJ, Rubin MA, Kleer CG. E-cadherin expression in primary carcinomas of the breast and its distant metastases. Breast Cancer Res 2003;5:R217-22

Lin TM, Chen CJ, Wu MM, Yang CS, Chen JS, Lin CC, Kwang TY, Hsu ST, Lin SY, Hsu LC. Hepatitis B virus markers in Chinese twins. Anticancer Res 1989;9:737-41

Liu H, Chao D, Nakayama EE, Taguchi H, Goto M, Xin X, Takamatsu JK, Saito H, Ishikawa Y, Akaza T, Juji T, Takebe Y, Ohishi T, Fukutake K, Maruyama Y, Yashiki S, Sonoda S, Nakamura T, Nagai Y, Iwamoto A, Shioda T. Polymorphism in RANTES chemokine promoter affects HIV-1 disease progression. Proc Natl Acad Sci USA 1999;96:4581-5

Lok AS, Lai CL, Wu PC, Wong VC, Yeoh EK, Lin HJ. Hepatitis $B$ virus infection in Chinese families in Hong Kong. Am J Epidemiol 1987;126:492-9

Marotta F, Vangieri B, Cecere A, Gattoni A. The pathogenesis of hepatocellular carcinoma is multifactorial event. Novel immunological treatment in prospect. Clin Ter 2004;155: 187-99

Marra F, DeFranco R, Grappone C, Milani S, Pastacaldi S, Pinzani M, Romanelli RG, Laffi G, Gentilini P. Increased expression of monocyte chemotactic protein-1 during active hepatic fibrogenesis: correlation with monocyte infiltration. Am J Pathol 1998;152:423-30

Medina J, Garcia-Buey L, Moreno-Otero R. Review article: immunopathogenetic and therapeutic aspects of autoimmune hepatitis. Aliment Pharmacol Ther 2003;17:1-16

Medina J, Arroyo AG, Sanchez-Madrid F, Moreno-Otero R Angiogenesis in chronic inflammatory liver disease. Hepatology 2004;39:1185-95

Moon EJ, Jeong CH, Jeong JW, Kim KR, Yu DY, Murakami S, $\mathrm{Kim} \mathrm{CW}$, Kim KW. Hepatitis $\mathrm{B}$ virus $\mathrm{X}$ protein induces angiogenesis by stabilizing hypoxia-inducible factor-1alpha. Faseb J 2004;18:382-4

Morgan L, Broughton Pipkin F, Kalsheker N. Angiotensinogen: molecular biology, biochemistry and physiology. Int J Biochem Cell Biol 1996;28:1211-22

Muhlbauer M, Bosserhoff AK, Hartmann A, Thasler WE, Weiss TS, Herfarth H, Lock G, Scholmerich J, Hellerbrand C. A novel MCP-1 gene polymorphism is associated with hepatic MCP-1 expression and severity of HCV-related liver disease. Gastroenterology 2003;125:1085-93

Nakamura A, Shimazaki T, Kaneko K, Shibata M, Matsumura T, Nagai M, Makino R, Mitamura K. Characterization of DNA polymorphisms in the E-cadherin gene (CDH1) promoter region. Mutat Res 2002;502:19-24

O'Brien WJ, Finlay JL, Gilbert-Barness EF. Patterns of antigen expression in hepatoblastoma and hepatocellular carcinoma in childhood. Pediatr Hematol Oncol 1989;6:361-5

Powell EE, Edwards-Smith CJ, Hay JL, Clouston AD, Crawford DH, Shorthouse C, Purdie DM, Jonsson JR. Host genetic factors influence disease progression in chronic hepatitis C. Hepatology 2000; 31:828-33

Ros JE, Libbrecht L, Geuken M, Jansen PL, Roskams TA. High expression of MDR1, MRP1, and MRP3 in the hepatic progenitor cell compartment and hepatocytes in severe human liver disease. J Pathol 2003;200:553-60

Rovin BH, Lu L, Saxena R. A novel polymorphism in the MCP-1 gene regulatory region that influences $M C P-1$ expression. Biochem Biophys Res Commun 1999;259:344-8

Shiota G, Okubo M, Noumi T, Noguchi N, Oyama K, Takano $\mathrm{Y}$, Yashima K, Kishimoto Y, Kawasaki H Cyclooxygenase-2 expression in hepatocellular carcinoma. Hepatogastroenterology 1999;46:407-12

Shiratori Y, Shiina S, Imamura M, Kato N, Kanai F, Okudaira T, Teratani T, Tohgo G, Toda N, Ohashi M, et al. Characteristic difference of hepatocellular carcinoma between hepatitis Band C- viral infection in Japan. Hepatology 1995;22:1027-33

Stephens M, Smith NJ, Donnelly P. A new statistical method for haplotype reconstruction from population data. Am J Hum Genet 2001;68:978-89

Stevens CE, Beasley RP, Tsui J, Lee WC. Vertical transmission of hepatitis B antigen in Taiwan. N Engl J Med 1975; 292:771-4

Szalai C, Kozma GT, Nagy A, Bojszko A, Krikovszky D, Szabo $T$, Falus A. Polymorphism in the gene regulatory region of MCP-1 is associated with asthma susceptibility and severity. J Allergy Clin Immunol 2001;108:375-81

Tagami A, Ohnishi H, Moriwaki H, Phillips M, Hughes RD. Fas-mediated apoptosis in acute alcoholic hepatitis. Hepatogastroenterology 2003;50:443-8

Tassopoulos NC, Papaevangelou GJ, Sjogren MH, Roumeliotou-Karayannis A, Gerin JL, Purcell RH .Natural history of acute hepatitis B surface antigen-positive hepatitis in Greek adults. Gastroenterology 1987;92:1844-50

Terada R, Yamamoto K, Hakoda T, Shimada N, Okano N, Baba N, Ninomiya Y, Gershwin ME, Shiratori Y. Stromal cell-derived 
factor-1 from biliary epithelial cells recruits CXCR4-positive cells: implications for inflammatory liver diseases. Lab Invest 2003;83:665-72

Thursz MR, Kwiatkowski D, Allsopp CE, Greenwood BM, Thomas HC, Hill AV. Association between an MHC class II allele and clearance of hepatitis B virus in the Gambia. N Engl J Med 1995;332:1065-9

Tian J, Tang Z, Xue Q. [Expressions of the metastasisassociated factors of a new human hepatocellular carcinoma cell line with highly metastatic potential]. Zhonghua Yi Xue Za Zhi 1999;79:470-2

Topol EJ, McCarthy J, Gabriel S, Moliterno DJ, Rogers WJ, Newby LK, Freedman M, Metivier J, Cannata R, O'Donnell CJ, Kottke-Marchant K, Murugesan G, Plow EF, Stenina O, Daley GQ. Single nucleotide polymorphisms in multiple novel thrombospondin genes may be associated with familial premature myocardial infarction. Circulation 2001;104:2641-4

Wald O, Pappo O, Safadi R, Dagan-Berger M, Beider K, Wald H, Franitza S, Weiss I, Avniel S, Boaz P, Hanna J, Zamir G, Eid
A, Mandelboim O, Spengler U, Galun E, Peled A. Involvement of the CXCL12/CXCR4 pathway in the advanced liver disease that is associated with hepatitis $C$ virus or hepatitis $B$ virus. Eur $\mathrm{J}$ Immunol 2004;34:1164-74

Wang Y, Song JP, Ikeda M, Shinmura K, Yokota J, Sugimura $\mathrm{H}$. Ile-Leu substitution (1415L) in germline E-cadherin gene $(\mathrm{CDH} 1)$ in Japanese familial gastric cancer. Jpn J Clin Oncol 2003:33:17-20

Watson RW. The rising incidence of hepatocellular carcinoma. N Engl J Med 1999;341:451-2

Wei Y, Van Nhieu JT, Prigent S, Srivatanakul P, Tiollais P, Buendia MA. Altered expression of E-cadherin in hepatocellular carcinoma: correlations with genetic alterations, beta-catenin expression, and clinical features. Hepatology 2002;36:692-701

Wessel J, Topol EJ, Ji M, Meyer J, McCarthy JJ. Replication of the association between the thrombospondin-4 A387P polymorphism and myocardial infarction. Am Heart J 2004; $147: 905-9$ 